\title{
Histology of Somatic Embryogenesis in Regal Geranium
}

\author{
D.P.M. Wilson, J.A. Sullivan', A.A. Marsolais, and M.J. Tsujita \\ Department of Horticultural Science, University of Guelph, Guelph, Ont., N1G 2W1, Canada
}

Additional index words. cotyledon, Pelargonium $\times$ domesticum, proembryo

\begin{abstract}
The origin and development of somatic embryos from petiole sections of Regal geranium (Pelargonium $\times$ domesticum Bailey 'Madame Layal') were studied using time-series sections at days $0,4,8,14$, and 24 . Somatic embryos originated as early as day 4 of culture. The proembryo stage resembled that of a zygotic embryo and the somatic embryos developed through the globular, heart-torpedo, and cotyledonous stages characteristic of in vivo zygotic embryogenesis. A suspensor-like structure was observed with some somatic embryos but this was not consistent. Strong evidence is presented to suggest that somatic embryos arose from single subepidermal parenchyma cells.
\end{abstract}

In vitro somatic embryogenesis occurs in a wide variety of species (Sharp et al., 1980; Williams and Maheswaran, 1986) including Zonal (Pelargonium $\times$ hortorum Bailey) and Regal (Pelargonium $\times$ domesticum) geranium (Marsolais et al., 1991). As a regeneration scheme, somatic embryogenesis shows promise for use in in vitro selection, protoplast, and transformation studies (Polito et al., 1989), as well as in commercial production of artificial seed. This latter application could be especially useful in geranium due to its high volume of sales and high cost per seed.

Somatic embryos (SEs) usually arise from single cells, but in some cases multicellular origins have been reported (Bhaskaran et al., 1988; Dos Santos et al., 1983; Haccius, 1978; Kim and Janick, 1989; Maheswaran and Williams, 1985; Nomura and Komamine, 1985; Wang and Janick, 1986; Wernicke et al., 1982). The origin of somatic embryogeny is crucial to the application of several techniques. For example, a single cell origin is important in genetic transformations (Polito et al., 1989) and other techniques where clonal fidelity is required to avoid chimeric embryos. Therefore, the objectives of this study were to examine the cellular origin and developmental sequence of Regal geranium somatic embryos.

\section{Material and Methods}

Source of explants. Explants were obtained from leaf petioles of greenhouse-grown plants of the diploid Regal geranium 'Madame Layal' (Pelargonium $\times$ domesticum Bailey). Plants were grown under ambient light levels in a University of Guelph greenhouse during May to September at $20 \pm 3 \mathrm{C}$. The petiole of the first expanded leaf was removed from nonflowering plants or plants that had been pruned after flowering. Petioles were surface sterilized in $1.7 \%$ sodium hypochlorite (commercial bleach) containing $20 \mathrm{ml} \cdot$ liter $^{-1}$ of Tween-20 (Sigma Chemical Co., St. Louis) for 20 min, followed by three, 5-min rinses with sterile distilled water. Bleached ends of the petioles were removed before the petioles were cut into 5-mm sections.

Culture medium. The basal medium for SE induction was the Geranium Callus Medium (GCM) (Marsolais et al., 1991), supplemented with 2,4-dichlorophenoxyacetic acid (2,4-D) (1.0 $\left.\mathrm{mg} \cdot \mathrm{liter}^{-1}\right)$ and benzyladenine (BA) $\left(1.0 \cdot \mathrm{mg} \cdot \mathrm{liter}^{-1}\right)$ and auto-

Received for publication 10 June 1993. Accepted for publication 28 Oct. 1993. We wish to thank the Ontario Ministry of Agriculture and Food for research support and the National Sciences and Engineering Research Council for the scholarship to D.P.M. Wilson. The cost of publishing this paper was defrayed in part by the payment of page charges. Under postal regulations, this paper therefore must be hereby marked advertisement solely to indicate this fact.

${ }^{1}$ To whom correspondence should be addressed. claved for $20 \mathrm{~min}$ at $120 \mathrm{C}$. About $20 \mathrm{ml} \mathrm{GCM}$ was dispensed into each $100 \times 15-\mathrm{mm}$ petri dish. Nine explant sections were cultured in each petri dish and constituted an experimental unit. Explant sections were placed on the induction medium for 4 days, then transferred to GCM medium without plant growth regulators for an additional 24 days. Experimental units were randomly arranged in a controlled environment cabinet at $240 \pm 0.2 \mathrm{C}$ with a $16 \mathrm{~h}$ photoperiod provided by cool-white fluorescent lamps. The lamps provided a photosynthetic photon flux (from 400 to $700 \mathrm{~nm}$ ) of from 30 to $40 \mu \mathrm{mol} \cdot \mathrm{m}^{-2} \cdot \mathrm{s}^{-1}$ as measured at shelf level with a quantum/radiometer/photometer (model 185A; LI-COR, Lincoln, Neb.). Petri plates were taken from random locations within the growth chamber at days $0,4,8,14$, and 24 for histological examination of developing SEs.

Histology. Explants were removed from the culture environment and immediately fixed in $2.5 \%$ aqueous glutaraldehyde solution ( $\mathrm{pH} \mathrm{6.8)} \mathrm{for} 3 \mathrm{~h}$. After day 8, it became necessary to cut the expanding explants into four smaller segments to ensure proper infiltration of the fixative. After fixation, explants were rinsed four times with distilled water (15 min per wash). Tissue samples were dehydrated with a graded ethanol series: $20 \mathrm{~min}$ in 50\%, $20 \mathrm{~min}$ in $70 \%, 30 \mathrm{~min}$ in $90 \%, 30 \mathrm{~min}$ in $95 \%, 30 \mathrm{~min}$ in $100 \%, 45 \mathrm{~min}$ in $100 \%$, and a maximum 21-day storage in $100 \%$ ethanol. Before embedding, an additional fourth rinse with $100 \%$ ethanol was performed. All explants were embedded in LR White resin (JBS-Supplies, Point-Claire, Quebec, Canada) using the following series of ethanol: LR White resin ratios: $2: 1$ for $30 \mathrm{~min}, 1: 1$ for 30 min; $1: 2$ for $30 \mathrm{~min}$, and two changes in 100\% LR White for $60 \mathrm{~min}$, each followed by a final change for $16 \mathrm{~h}$. Embedded explants were then placed in gelatin capsules with fresh LR White and allowed to polymerize in an oven at $60 \mathrm{C}$ for $24 \mathrm{~h}$.

Three petioles were randomly selected from each petri dish and considered as replications. Embedded tissues were sectioned at 1 to $2 \mu \mathrm{m}$ and mounted on glass slides. Tissues were stained for 15 sec with a solution of $1 \%$ methylene blue $(\mathrm{w} / \mathrm{v})$ and $1 \%$ sodium borate $(\mathrm{w} / \mathrm{v})$ and rinsed with distilled water before microscopic examination. Measurement of cell and parenchyma width were made with an eyepiece micrometer and by converting eyepiece units to millimeters. Measurements were made by observing 10 random microscope fields for each replicate at the developmental intervals: $0,4,8,14$, and 24 days. For cell dimension calculations, an average of 10 cells per field was used.

\section{Results}

Petioles of 'Madame Layal' used for SE induction were char- 


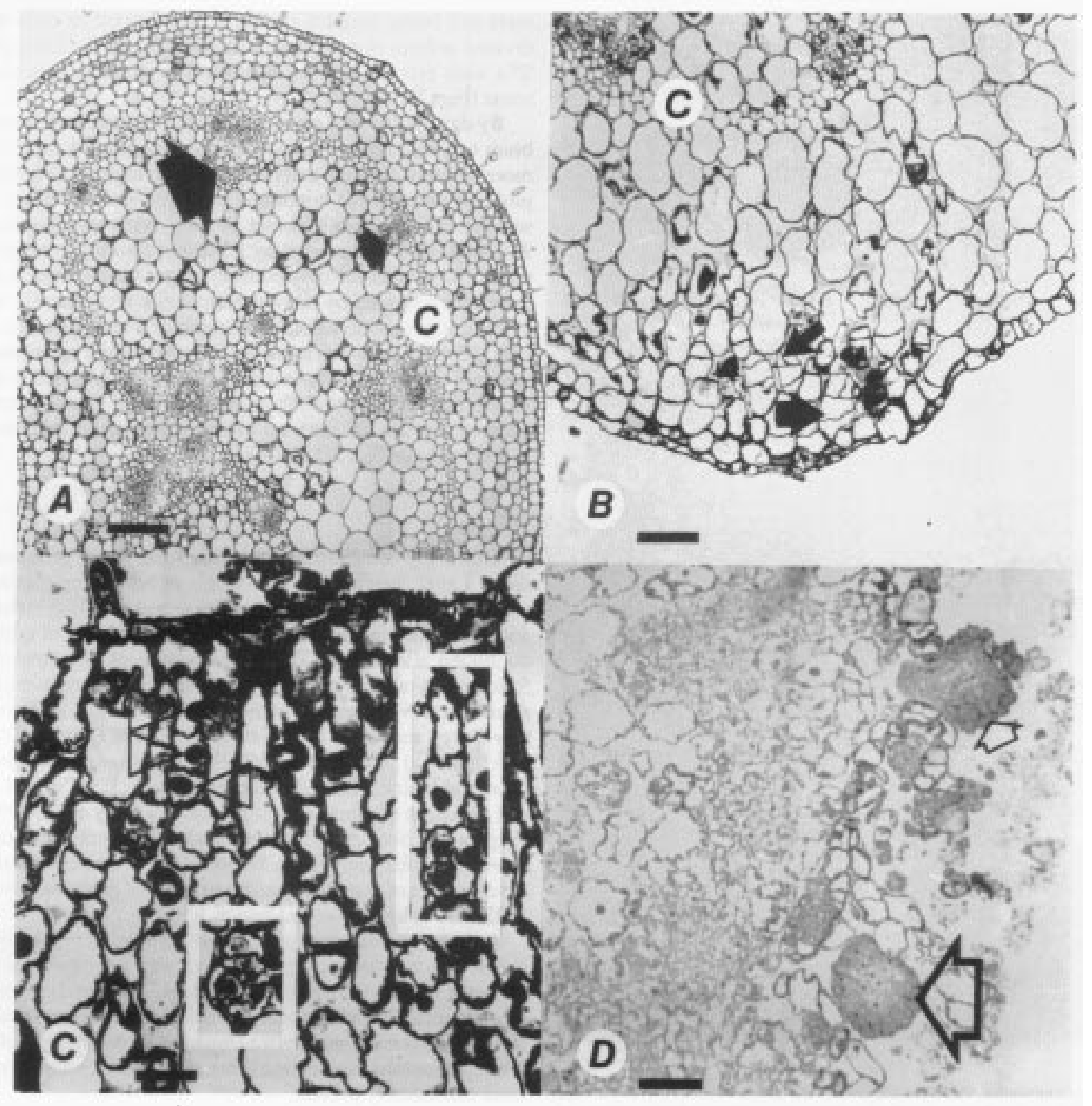

Fig. 1. Development of somatic embryos of Pelargonium $\times$ domesticum Bailey 'Madame Layal'. (A) Cross section of petiole at day 0, before induction of somatic embryogenesis. Large arrow indicates major vascular bundle; small arrow indicates minor vascular bundle. Cambial region $=\mathrm{c}$. Bar $=130 \mu \mathrm{m}$. $(\mathbf{B})$ Cross section of petiole after 4 days on induction medium. (Note the overall expansion of cells.) Large arrow indicates transverse cell division; small arrow indicates a longitudinal division in the terminal cell. Cambial region $=\mathrm{c}$. Bar $=80 \mu \mathrm{m}$. (C) Cross section of petiole after 4 days on induction medium. Open arrrows indicate cells that have undergone a series of periclinal and anticlinal divisions to form embryogenic centers like those outlined in white. Bar $=58 \mu \mathrm{m}$. (D) Cross section of petiole after 8 days of culture. Large arrow indicates discrete globular somatic embryo, small arrow indicates early heart-torpedo stage somatic embryo. Bar $=60 \mu \mathrm{m}$.

acterized by having five main, and up to six minor, vascular bundles, with large, central pith parenchyma cells (Fig. 1A). A double layer of procambial cells connected the vascular bundles, outside of which was a layer of six to seven cells of large, round cortical parenchyma cells. The epidermis was a single layer of cuboid shaped cells occasionally having trichomes composed of one to five cells (Fig. 1A). After 4 days on induction medium, cell expansion and infolding of the cell walls had occurred (Fig. 1B). This may have been an artifact caused by the induction treatment, softening of the cell walls, or the fixation procedures. The number of cells in the cortex remained fairly constant (i.e., six to seven cell layers). However, cells had elongated considerably, increasing the cortex width from $190 \mu \mathrm{m}$ at day 0 to $390 \mu \mathrm{m}$ at day 4 (data not presented). During the interval between days 0 to 4, parenchyma and epidermal cell widths increased $57 \%$ and $100 \%$, respectively.

In certain isolated regions, subepidermal (i.e., cortical-parenchyma) cells had two to three transverse cross-walls (Fig. 1C). The first periclinal division formed a two-celled dyad (Fig. 1B) with a subsequent division forming a three-celled proembryo (Fig. 1C). In the localized regions of subepidermal cell divisions, the epidermis was usually normal in appearance (Fig. 1B), but in a few cases a second layer of cuboid epidermal cells was present. The entire region, described as having subepidermal cell division activity, was termed an "embryogenic center" (EC). By day 8 , some cells of the central pith had divided, as evidenced by cells with cross-walls. Division of procambial cells also was 


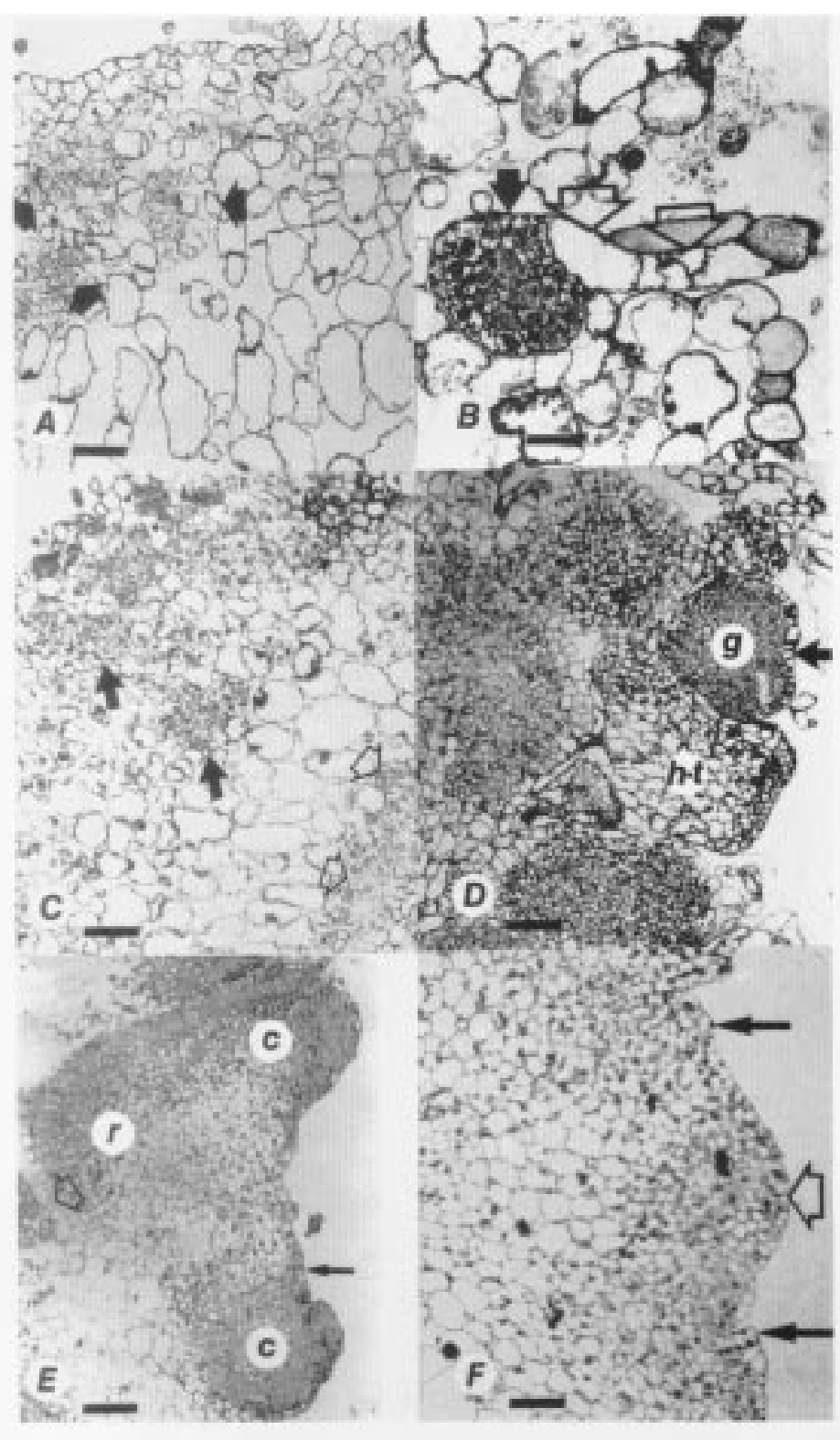

Fig. 2. Development of somatic embryos of Pelargonium $\times$ domesticum (Bailey) 'Madame Layal'. (A) At day 8 of culture, the arrows indicate regions of disorganized subepidermal meristematic activity with incomplete globular embryo formation. Bar $=60 \mu \mathrm{m}$. (B) Longitudinal section on day 8 of culture showing globular embryo (solid arrow) with a suspensor-like structure (open arrows). Bar $=27 \mu \mathrm{m}$. (C) At day 14 of culture the solid arrows indicate regions of unorganized subepidermal meristematic activity. This is clearly distinct from the active cell divisions occurring in the cambial region of the petiole (open arrows). Bar $=140$ $\mu \mathrm{m}$. (D) Longitudinal section of petiole at day 14 of culture; $g=$ globular embryo with distinct surrounding epidermis (solid arrow), h- $\mathrm{t}=$ heart-torpedo stage embryo. Bar $=63 \mu \mathrm{m}$. (E) Longitudinal section of a cotyledonous somatic embryo at day $24 ; \mathrm{c}=$ meristematic areas at cotyledon apices, $\mathrm{r}=$ root pole, and distinct epidermis indicated by solid arrow. Open arrow indicates the clear separation of the somatic embryo from the parental explant by a limiting epidermis. Bar $=1.95 \mu \mathrm{m}$. $(\mathbf{F})$ Twenty-four-day-old cotyledonous somatic embryo, clearly separated from the parent explant by a limiting epidermis (open arrow). The solid arrows indicate the first leaf primordia. Bar $=130 \mu \mathrm{m}$.

observed. In the ECs subepidermal cortical cells had undergone several cell divisions illustrated by the globular clusters of 20 to 100 cells that often erupted through the epidermis (Fig. 1D). These clusters of cells were composed of small, densely cytoplasmic cells, clearly delineated from surrounding parenchyma cells by an epidermal-like layer(Fig. 2D). It is important to observe, however, that some ECs were still being initiated on day 8 as indicated by cells that had divided to form two to three cross walls (Fig. 2A). Early globular SEs were present, and a suspensor-like structure was visible in some (Fig. 2B).

By day 14, the pith cells had divided further, and the procambium had undergone extensive division forming a layer of 14 or more actively dividing cells with dense cytoplasm (Fig. 2C). The globular proembryos continued to divide and increased in size, some reaching the late globular, or early, heart-torpedo stage (Fig. 2D), and were surrounded by a distinct limiting epidermis. Somatic embryos at the cotyledonary stage, visible around day 24 , were characterized by having many cells with densely staining cytoplasm at the cotyledon apices, apical meristems, and root pole (Fig. 2E). An early cotyledonous SE with a large apical meristem and well-developed first-leaf primordium is illustrated in Fig. 2F. In all samples observed, there was a distinct limiting epidermis surrounding the SE with no visible vascular connection to the parent explant (Fig. 2D and E).

\section{Discussion}

This study demonstrated that SEs from Regal geranium 'Madame Layal' originated from single subepidermal parenchyma cells of immature petiole tissue. It was apparent that induction of somatic embryogenesis began on, or before, day 4 of culture and continued after day 8. The initial pattern of periclinal division followed by anticlinal division in proembryo development was similar to previous reports of the unicellular origin of SEs in alfalfa (Medicago sativa L.) (Dos Santos et al., 1983), borage (Borago officinalis L.) (Quinn et al., 1989), celery (Apium graveolens L.) (Kim and Janick, 1989), clover (Trifolium sp. L.) (Cui et al., 1988), and carnation (Dianthus caryophyllus L.) (Frey et al., 1992). The longitudinal divisions of the terminal cell to form the proembryo observed in this study (Figs. 1B and C) were also observed during development of zygotic proembryos of zonal geranium (Tsai et al., 1973) and celery (Kim and Janick, 1989).

A suspensor-like structure was observed in some SEs, although it was not consistently present and was not observed in SEs maturing beyond the heart-torpedo stage. The variable occurrence of a suspensor has also been reported in alfalfa (Dos Santos et al., 1983) and jojoba (Simmondsia chinensis Link) (Wang and Janick, 1986), in contrast to carnation (Frey et al., 1992), where suspensors were consistently present.

Localized regions of meristematic activity in the terminal regions of heart-torpedo and cotyledonous somatic embryos suggested establishment of polarity in the developing structure, similar to in vivo embryogenesis (Grossman, 1982) in geranium. The presence of an apical dome and first leaf primordia reported here for somatic embryos is similar in appearance to the 18-day zygotic embryos of geranium described by Harney (1976). If somatic embryogenesis requires 4 days for induction, then at day 24 the in vitro SE is remarkably similar to the 18 -day in vivo embryo with respect to morphology and development rate.

It is important to note that root meristematic activity was not consistently observed in this material. Yet, the evidence of root meristematic activity is consistent with a similar report of somatic embryogenesis in celery (Kim and Janick, 1989) and may simply represent asynchronous development of SEs. Regardless, visible development of roots has been observed in geranium within 7 days if 28- to 42-day-old SEs were removed from the explant, desiccated, and then placed on basal medium for germination (Marsolais et al., 1991). This suggests a longer period of maturation may be required to achieve consistent root pole development in SEs. 
Geranium SEs of this study were similar to SEs of other studies where morphological maturity was observed before physiological maturity (Dos Santos et al., 1983; Kim and Janick, 1989; Quinn et al., 1989; Williams and Maheswaran, 1986). Desiccation studies on geranium SEs (Marsolais et al., 1991) have confirmed that physiological maturity follows morphological maturity. Grossman (1982) and Harney (1976) reported that morphological maturity was achieved by day 15 and day 18, respectively, for zygotic embryos of Pelargonium, yet physiological maturity was not reached until day 32 and day 39 for Pelargonium $\times$ hortorum and Pelargonium $\times$ zonale $\mathrm{SE}$, respectively. Since the early stages of somatic embryogenesis development seem to correspond with the description of zygotic embryogenesis (Harney, 1976), it may prove advantageous to leave the SEs in culture for the additional 18 days of growth to enable them to mature physiologically. Other specific treatments designed to improve maturity may also be advantageous.

The structures observed in this study can be considered as SEs because of the bipolarity of the well-developed root and apical meristem. The unicellular origin from somatic cells, developmental sequence, and lack of a vascular connection to the parent explant support the conclusion that these embryos are indeed somatic embryos.

\section{Literature Cited}

Bhaskaran, S., A.J. Neumann, and R.H. Smith. 1988. Origin of somatic embryos from cultured shoot tips of Sorghum bicolor (L.) Moench. In Vitro Cellular Dev. Biol. 24:947-950.

Cassells, A.C. 1979. The effect of 2,3,5-triiodobenzoic acid on caulogenesis in callus cultures of tomato and Pelargonium. Physiol. Plant. 46:159164

Cui, D., J.R. Myers, G.B. Collins, and P.A. Lazzari. 1988. In vitro regeneration in Trifolium. I. Direct somatic embryo-genesis in T.rubens (L.). Plant Cell Tissue Organ Cult. 15:33-45.

Dos Santos, A.V.P., E.G. Cutter, and M.R. Davey. 1983. Origin and development of somatic embryos in Medicago sativa L. (alfalfa). Protoplasma 117:107-115.
Frey, L., Y. Saranga, and J. Janick. 1992. Somatic embryogenesis in carnation. HortScience 27:63-65.

Grossman, H.H. 1982. Anatomy and morphology, p. 331-340. In: J.W. Mastalerz and E.J. Holcomb (eds.). Geraniums III. Flower Growers, Univ. Park, Pa.

Haccius, B. 1978. Question of unicellular origin of non-zygotic embryos in callus cultures. Phytomorphology 28:74-81.

Harney, P.M. 1976. The origin, cytogenetics, and reproductive morphology of the zonal geranium: A review. HortScience 11: 189-195.

Kim, Y.H. and J. Janick. 1989. Origin of somatic embryos in celery tissue culture. HortScience 24:671-673.

Maheswaran, G. and E.G. Williams. 1985. Origin and development of somatic embryos formed directly on immature embryos of Trifolium repens in vitro. Ann. Bot. 56:619-630.

Marsolais, A.A., D.P.M. Wilson, M.J. Tsujita, and T. Senaratna. 1991. Somatic embryogenesis and artificial seed production in zonal (Pelargonium $\times$ hortorum Bailey) and Regal (Pelargonium $\times$ domesticum Bailey) geranium. Can. J. Bot. 69:1188-1193.

Nomura, K. and A. Komamine. 1985. Identification and isolation of single cells that produce somatic embryos at a high frequency in a carrot suspension culture. Plant Physiol. 79:988-991.

Polito, V.S., G. McGranahan, K. Pinney, and C. Leslie. 1989. Origin of somatic embryos from repetitively embryogenic cultures of walnut (Juglans regia L.): Implications for Agrobacterium-mediated transformation. Plant Cell Rpt. 8:219-221.

Quinn, J., J.E. Simon, and J. Janick. 1989. Histology of zygotic and somatic embryogenesis in borage. J. Amer. Soc. Hort. Sci. 114:516-520.

Sharp, W.R., M.R. Sondahl, L.S. Caldas, and S.B. Maraffa. 1980. The physiology of in vitro asexual embryogenesis. Hort. Rev. 2:268-310.

Tsai, A.H., P.M. Harney, and R.L. Peterson. 1973. Megasporogenesis and megagametogenesis in Pelargonium $\times$ hortorum. Can. J. Bot. 51:607612.

Wang, Y.C. and J. Janick. 1986. Somatic embryogenesis in jojoba. J. Amer. Soc. Hort. Sci. 111:281-287.

Wernicke, W., I. Potrykus, and E. Thomas. 1982. Morphogenesis from cultured leaf tissue of Sorghum bicolor - the morphogenetic pathways. Protoplasma 111:53-62.

Williams, G.E. and G. Maheswaran. 1986. Somatic embryogenesis: factors influencing coordinated behavior of cells as an embryogenic group. Ann. Bot. 57:443-462. 